AGRICULTURE AND BIOLOGY JOURNAL OF NORTH AMERICA

ISSN Print: 2151-7517, ISSN Online: 2151-7525, doi:10.5251/abjna.2010.1.5.841.844

(C) 2010, ScienceHuß, http://www.scihub.org/ABJNA

\title{
The effect of type and levels of animal protein supplements on the growth rate of rats
}

\author{
${ }^{1}$ Addass, P.A., ${ }^{1}$ Midau, A, ., ${ }^{2}$ Perez, I.K.A and ${ }^{2}$ Magaji, M.Y \\ ${ }^{1}$ Adamawa State University, Animal Production Department, P.M.B 25 Mubi Adamawa State. \\ Nigeria \\ ${ }^{2}$ Federal University of Technology Yola, Adamawa State, Nigeria. \\ ABSTRACT
}

\begin{abstract}
The experiment was designed to examine the effect of types and levels of animal protein supplements on feed intake, weight gain, feed conversion ratio and feed digestibility in rats. Thirty (30) weaning albino rats of the Wister strain were subjected to five dietary treatments, diet 1 (control diet) contained soybean meal only as a source of protein concentrate, diets 2 and 3 were supplemented with $2.5 \%$ and $5.0 \%$ levels of fish meal (FM) respectively while diets 4 and 5 were supplemented with blood meal (BM) at $2.5 \%$ and $5.0 \%$ levels respectively. Animals fed on the supplemented diets at $5.0 \%$ levels of BM and FM had the highest weight gain of $3.14 \mathrm{~g}$ and $3.0 \mathrm{~g} /$ day respectively, followed by animals fed on supplemented diets at $2.5 \%$ levels of BM and FM (2.9g and $2.82 \mathrm{~g} /$ day respectively). Animals fed unsupplemented soybean diet had the least weight gain of $2.51 \mathrm{~g} /$ day. However type and levels of protein supplement had no significant effect on the growth rate of the rats.
\end{abstract}

Keywords: Blood meal; fish meal; growth rate; rats

\section{INTRODUCTION}

FAO (1959) estimated that the demand for animal products in the developing countries among which Nigeria is one ought to increase by $4.5 \%$ annually in the coming 20years. This expansion could provide for $2.2 \%$ of demographic growth of animal product for $2.3 \%$ supposed increase in revenue. If one relates this to what has happen for the large ruminants over the last 15 years in this countries especially Nigeria, the production of meat was only increased by $2.5 \%$ and that of milk by $3.0 \%$. This is to say that considerable efforts will have to be made to meet the demand for animal products.

Self sufficiency in food production in order to meet the food demand of the ever increasing human population is one of the primary objectives of both federal and state government of this country. Successive and present government have launched several agricultural programmes in a bid to boost food production such programmes include; operation feed the nation (OFN), Green Revolution, Back to land, Directorate of Food, Roads and Rural Infrastructures (DFFRI) and Fadama II. Boosting food production includes both the production of more food crops and animal products for human consumption. In the area of animal production, over $50 \%$ of products cost is on feeds, this ranges from $40 \%$ for ruminants to $75-80 \%$ for monogastric (Church, 1977). Therefore it has become necessary for the government and animal scientist to identify and evaluate available and cheep sources of feed ingredients such as blood meal and soybean meal as source of protein. Animals and their products can be produced more economically with more balanced feeds.

In considering the above constraints to animal production, the research was designed to investigate the effect of types and levels of protein on the growth performance of rats. Recently in Nigeria, rats and rabbit production has gained considerable interest because the price of meet from conventional meat sources such as cattle, sheep and goats, poultry and pigs cannot be afforded by many Nigerians. Consequently, hardly can many Nigerians meet their daily protein requirement. Oyenuga (1975) reported that demand for animal protein in Nigeria between 1985 and 1987 have out striped supply by the following margins beef $(36.28 \%)$, Goat meat $(33.49 \%)$, poultry $(30.30 \%)$, pork meat $(25.25 \%)$, bush meat (32.51\%), fish (27.08\%) and milk products by $(39.40 \%)$. One of the strategies proposed for combating these shortages is contained in a report of the green revolution committee (GRC)(1983). This consists essentially of providing adequate quantity and quality of feed to the various classes of livestock 
in Nigeria in order to increase their productivity and hence increase the supply of animal protein to Nigerians.

\section{MATERIALS AND METHODS}

Experimental rats and management: Thirty weaning albino rats of the wister strain obtained from the Nigerian Institute for Trypanosomiasis Research (NITR) substation Vom, plateau State of Nigeria were used. All rats ranged from 3-4 weeks old and their live weight ranged from $67.5-68.6 \mathrm{~g}$. They were randomly selected and distributed into five groups of six rats per group and kept in metabolism cages. There was a preliminary period of seven (7) days during which the animals were fed on broiler starter mash. After the preliminary period, the experimental diets were fed at $10 \%$ of the animals body weight. The experiment lasted for 4 weeks (28) days.

Ration Formulation: The ingredients used to formulate the diets were blood meal, fish meal, soybean meal, groundnuts hay meal, grounded maize, salt, bone meal, mineral/vitamin premixes. Five diets were formulated for the research. Soybean meal was used as the basal plant protein source while fish meal and blood meal were used as supplementary animal protein at varying levels. Diet one was the control diet containing plant protein (soybean) as the main source of protein. Diets 2 and 3 were supplemented with animal protein (fish meal) at 2.5 and $5.0 \%$ levels while diets 4 and 5 were also supplemented with animal protein (blood meal) at 2.5 and $5.0 \%$ levels respectively.

Data Collection: The rats were placed on the different experimental diets for 4 weeks during which period data were collected on the following and analyzed.

(i) feed intake (g): feed was given twice daily for the rats on each treatment, in the morning and evening and the feed residues were collected and weighed after drying in the oven at $80^{\circ} \mathrm{C}$ for 48 hours.

(ii) Body weight changes (g): Initial live weight of the rats were taken after the preliminary period at the beginning of the experiment and were subsequently weighed weekly throughout the 4 weeks period. Weights were recorded based on the treatment. The weight gained were obtained by subtracting the initial weight from the final weights.

\section{(iii) Feed conversion ratio}

Calculated as feed intake (g) per weight gained.

$\mathrm{FRC}=$ feed intake $(\mathrm{g})$.

$$
\text { Weight gained (g) }
$$

Chemical Analysis of Diets and Feaces: Chemicals analysis was carried out to determine the chemical composition of the diets and feaces according to the methods of the A.O.A.C. (1975).

Statistical Analysis and Experimental Design: The mean values obtained for the various measurements were subjected to analysis of variance according to the method of steel and Torrie (1960). Test for significance of the means was by Duncan (1955) multiple range test. The experimental design was a completely randomized design.

Table 1. Composition of the experimental diet (\%)

\begin{tabular}{|l|l|l|l|l|l|l|}
\hline & \multicolumn{3}{|l|}{ Diets } \\
\hline Ingredients & $\begin{array}{l}\% \\
\mathrm{CP}\end{array}$ & 1 & 2 & 3 & 4 & 5 \\
\hline Maize & 9 & 64.20 & 65.90 & 67.34 & 67.80 & 71.50 \\
\hline Soybean & 40 & 22.30 & 18.10 & 14.20 & 16.20 & 10.00 \\
\hline Fish meal & 60 & - & 2.50 & 5.00 & - & - \\
\hline Blood meal & 85 & - & - & - & 2.50 & 5.00 \\
\hline $\begin{array}{l}\text { Groundnuts } \\
\text { meal }\end{array}$ & 12 & 10.00 & 10.00 & 10.00 & 10.00 & 10.00 \\
\hline Bone meal & 0 & 2.00 & 2.00 & 2.00 & 2.00 & 2.00 \\
\hline Salt & 0 & 0.50 & 0.50 & 0.50 & 0.50 & 0.50 \\
\hline $\begin{array}{l}\text { Min/vit } \\
\text { premixes }\end{array}$ & 0 & 1.00 & 1.00 & 1.00 & 1.00 & 1.00 \\
\hline
\end{tabular}

Min=Mineral, Vit=Vitamin

\section{RESULT AND DISCUSSION}

The feed intake, growth performance, feed conversion ratio (FCR) dry matter and Crude protein digestibility values are shown in Table 2. 
Table 2. Mean feed intake, weight gain, feed conversion ratio and nutrients digestibility of feed by rats.

\begin{tabular}{|c|c|c|c|c|c|c|c|}
\hline & gation & a & & \multicolumn{2}{|l|}{ DIETS } & & \\
\hline & 1 & 2 & 3 & 4 & 5 & & \\
\hline Measurement & (SB) & $\begin{array}{l}(\mathrm{SB}+2.5 \% \\
\mathrm{FM})\end{array}$ & $\begin{array}{l}(\mathrm{SB}+5.0 \% \\
\mathrm{FM})\end{array}$ & $\begin{array}{l}(\mathrm{SB}+2.5 \% \\
\mathrm{BM})\end{array}$ & $(\mathrm{SB}+5.0 \% \mathrm{BM})$ & SE & $P=0.05$ \\
\hline Feed intake/day (g) & 21.67 & 20.13 & 19.66 & 21.85 & 19.72 & 0.232 & NS \\
\hline Growth performance/day (g) & 2.52 & 2.82 & 3.00 & 2.90 & 3.14 & 0.170 & NS \\
\hline Feed Conversion Ratio (FCR) & 8.63 & 7.14 & 6.57 & 7.54 & 6.26 & 0.723 & NS \\
\hline Digestibility of DM (\%) & 88.14 & 81.00 & 77.31 & 83.54 & 74.00 & 3.080 & NS \\
\hline Crude protein digestibility & 95.05 & 91.77 & 87.47 & 91.43 & 86.83 & 2.410 & NS \\
\hline
\end{tabular}

NS=Not significant, $\mathrm{SB}=$ Soybean, $\mathrm{FM}=$ Fish meal, BM=Blood meal, DM=Dry matter SE=Standard error

Feed intake: The feed intake of the rats on the different diets is shown on Table 2. The highest mean intake value for the experimental periods was recorded on diet 4containing $2.5 \%$ level supplementary blood meal being $21.85 \mathrm{~g} /$ day whereas diet 3 containing $5.0 \%$ level of supplementary fish meal recorded the least (19.66\%). This might have occurred due to high ash content of fish meal and also the fat content resulting to low palatability of the diet. However statistical analysis has shown that there was no significant difference $(P<0.05)$ in the intake of the various diets. Therefore there was no advantage of supplementing soybean with animal protein with regards to feed intake.

The result of feed intake obtained agreed with the findings of Njike, (1977) who reported that improving broiler diet with cotton seed cake (CSC) had no significant effect on feed consumption. North, (1972) also found that birds tend to eat much of the common available feeds than the unfamiliar or unreadily available feeds. Ogunkule, (1994) also found out that supplementation had no effect on feed consumption in rat fed varying levels of cotton seed cake.

Growth rate (g): Rats fed on diet 5 containing 5.0\% level of supplementary blood meal had the highest daily weight gain of $3.14 \mathrm{~g}$. Least gain was recorded on animals fed diet 1 containing soybean as the main source of protein $(2.51 \mathrm{~g} /$ day). Diets 3 and 5 which were supplemented with $5.0 \%$ level of fish meal and blood meal tend to produce better gain than the animals fed on diets 2 and 4 which were also supplemented at $2.5 \%$ levels of fish meal and blood meal $(2.82 \mathrm{~g}$ and $2.90 \mathrm{~g} /$ day) respectively. The control diet 1 having soybean only had the least gain of $2.51 \mathrm{~g} /$ day. This might indicated that supplementary plant protein with animal protein gives better result with increasing levels of supplementation.

Wilson (1964) reported that rats has been known to posses very efficient regulatory mechanism to adjust the feed intake per energy demand within a specific range of caloric density. On the other hand, rats do not consume feed to meet their protein requirements, as a result the sub optimal level of dietary protein in relation to energy may become a factor to limiting growth. Kakade, et al. (1992) reported that maximum protein efficiency values were obtained only when soybean was well processed and subjected to further supplementation by animal protein.

Feed conversion ratio (FCR): The values of FCR, treatment 1 containing soybean alone had the highest value of $8.63 \%$ while the supplemented diets at $2.5 \%$ levels of fish meal and blood meal had 2.14 and $7.54 \%$ respectively. The supplementary diets at $5.0 \%$ levels of FM and BM gave the values of 6.57 and 6.27 respectively. The FCR decreases with increasing levels of supplementation. This is suggesting that the animals eat less of supplemented diets per unit weight gain, which may be an indication that the supplemented diets were likely to be of higher quality than the unsupplemented soybean diet. However no significant difference was obtained among the diets with regard to FCR of all the animals.

The highest FCR was obtained on unsupplemented soybean diet which was also the diet consumed the highest, though animals tends to gain the least weight. This may be due to the antinutritional factors associated with soybean. This agreed with the findings of Jung and Fahey (1983), Huisman and Jansman (1992) who reported that increasing intake in antinutritional factors increases feacal output and decreases nutrients efficiency level.

Dry matter digestibility of diets (\%): The result of the dry matter digestibility have shown that unsupplemented diet had the highest digestibility of $88.14 \%$ while diet 5 supplemented with $5.0 \%$ level of BM had the least digestibility (73\%). This might have occurred due to the less digestibility associated with BM. 
Dry matter digestibility was found to be decreasing with level of supplementation of (FM and BM) soybean. Highest digestibility was obtained on the supplemented soybean meal diet while lowest was obtained on diets 5 supplemented with $5 \%$ BM and FM. This might have occurred due to high ash content of fish meal and poor digestibility associated with BM. These findings agreed with the result of Liener and Wada (1963) who reported that the poor digestibility of BM by rats and on soybean was due to the soybean trypsin inhibitor which might inhibited the absorption of nitrogen and sulphur from the digestive tract of rats.

Crude Protein Digestibility (\%): The result was similar to that of dry matter digestibility which showed no significant difference. Diet 1 hadthe highest digestibility value of $95.05 \%$ while diet 5 had the lowest of $86.83 \%$.

The results agreed with the findings of Donkoh et al. (1994) who reported that highly considerable amount of bone in raw material used for meat and bone meal manufacture resulted in meals low in protein and essential amino acid but high in ash which depressed digestibility. At higher level of FM digestibility decreases while higher at low level of FM (77.31 and $81 \%$ respectively) at 5 and $2.5 \%$ levels.

\section{REFERENCES}

A.O.A.C (1975). Official Method of Analysis. Association of Official Analytical Chemists. $11^{\text {th }}$ edition. Washing ton DC.

Church, D.C. (1977). Livestock Feeds and Feeding United State of America. Pp133-147.

Donkoh, A.M., Moughan, P.J and Smith, W.C (1994). True ideal digestibility of amino acids in meat and bone meal for the growing pig, application of a routine rat digestibility assay. Journal of Animal Feed Science and Tchnology49: (1994). 73-85.

Duncan D.B (1955). Multiple range and Multiple F-test. Biometrics 11: 1-42.

FAO Production year book, 13. (1959). Food and Agricultural Organization, Rome.

Ogunkule, M.M. (1994). Effect of replacing ggroundnuts cake with cotton seed cake at varying levels on the performance and organ weight of rats. Post graduate thesis, A.T.B.U Bauchin (1994).

Oyenuga V.A. (1975). The challenges of (1980) in Nigeria Agriculture, (Livestock) sector, Journal of Animal Production. 2: 7-11 